\title{
RELATIONSHIP BETWEEN URBAN RUNOFF POLLUTANT AND CATCHMENT CHARACTERISTICS
}

\author{
Jorge Rodriguez-Hernandez ${ }^{1}$, Andrés H. Fernández-Barrera ${ }^{2}$, Valerio C.A. Andrés-Valeri ${ }^{3}$, \\ Angel Vega-Zamanillo ${ }^{4}$, Daniel Castro-Fresno ${ }^{5}$ \\ ${ }^{1}$ Assistant Professor, Department of Transports, Civil Engineering School (ETSICCP), \\ Universidad de Cantabria, Santander, Spain. \\ ${ }^{2}$ Assistant Professor, Construction Engineering School, Faculty of Engineering, \\ Pontificia Universidad Católica de Valparaíso, Valparaíso, Chile \\ ${ }^{3}$ Masters Research Student, Civil Engineering School (ETSICCP), \\ Universidad de Cantabria, Santander, Spain. \\ ${ }^{4}$ Assistant Professor, Department of Transports, Civil Engineering School (ETSICCP), \\ Universidad de Cantabria, Santander, Spain. \\ ${ }^{5}$ Professor, Department of Transports, Civil Engineering School (ETSICCP), \\ Universidad de Cantabria, Santander, Spain.
}

*Corresponding author: T. +34 942201550, F. +34 942201703, e-mail jorge.rodriguez@unican.es

\begin{abstract}
A lot of research has been done to determine levels of contamination in runoff from urban and rural catchment areas. Some authors compare their results with other authors, or look for relationships between the variations of pollutant concentration and the catchment characteristics but they seldom focus on determining the statistical significance of their results. This paper presents a review of 37 papers selected from a total of 169 papers consulted about runoff water quality throughout the world (America, Asia and Europe). The results
\end{abstract}


presented in these 37 papers have been reviewed and statistically analyzed in order to evaluate the influence of catchment area characteristics (location, catchment area size, average daily traffic and type of land use) on the stormwater runoff pollution. It has been concluded that for the cases studied, most of the results about the polluting agents studied are comparable and no important element of the catchment characteristics had significant influence on the pollutants' concentration.

\title{
KEYWORDS
}

Water quality; Stormwater; Non-point pollution; Runoff; EMC.

\section{INTRODUCTION}

The contamination of rain water caused by the surface wash off has been under study for about 30 years. In this time, the investigations have demonstrated that the polluting agents present in the runoff have a mainly anthropogenic origin and can negatively affect the environment and the community (Boving and Neary, 2006).

\begin{abstract}
A number of investigations analyze the quantity of runoff pollution, some of them comparing their results with other research results in other catchment areas (Prestes et al. 2006; Tuccillo 2006; Zhang et al. 2008). These comparisons are only quantitative and they do not focus on determining whether the comparison of the results has statistical significance.
\end{abstract}


Göbel et al. (2006) and Mitchell (2005) go beyond the simple comparison, building international databases. The former compiled a matrix of pollutant load in relation to land use, and the latter found that the majority of the pollutant agents have a logarithmic distribution when they are grouped by land use.

Another analysis carried out in diverse studies consists in looking for relationships between the variations of pollutant concentration and the catchment characteristics (Göbel et al. 2006; Mitchell 2005; Kayahanian et al. 2007; Crabtree et al. 2006; Brown and Peake 2006; Soller et al. 2005; Lee and Bang 2000; Irish et al. 1998). These studies attempt to find out whether it is possible to determine the concentration of several pollutants by analyzing only some of the associated factors, especially those that can be easily and economically assessed.

These factors include catchment area size, average daily traffic and wind direction; other factors are related to precipitation characteristics such as intensity, magnitude, duration and dry periods between events. Some researchers recommend precaution before extrapolating their results to other catchment areas (Khan et al. 2006) because the pollutant concentrations and their relationships could vary form one place to another.

In this context, the objective of this paper is to review the event mean concentration (EMC) of the main runoff pollutants: total suspended solids (TSS), oils and grease $(\mathrm{O} \& \mathrm{G})$, zinc $(\mathrm{Zn})$, copper $(\mathrm{Cu})$ and chemical oxygen demand (COD); from different studied catchment areas across the world. This is done by 
reviewing different available data from published papers in order to evaluate the influence of catchment area characteristics such as location, catchment area size, average daily traffic and type of land use, on the stormwater runoff pollution.

\section{METHODOLOGY}

The first step in this analysis consisted in creating a database of runoff pollutant concentrations from different catchment areas. These data were extracted from the published articles, obtained by an extended consultation of the existing information in the main web search engines of scientific and technological information. The articles grouped by continent are:

- America: Thomson et al. (1997), Barrett et al. (1998a, 1998b), Charbeneau and Barrett (1998), Sansalone et al. (1998), Wu et al. (1998), Lau et al. (2002), Dean et al. (2005), Behera et al. (2006), Han et al. (2006), Heyvaert et al. (2006), Khan et al. (2006), Flint and Davis (2007), Fulkerson et al. (2007), Li et al. (2008).

- Asia: Lee et al. (2005), Kim et al. (2007), Gan et al. (2008).

- Europe: Stotz and Krauth (1994), Barbosa and Hvitved-Jacobsen (1999), Legret and Colandini (1999), Pettersson et al. (1999), Gnecco et al. (2005), Hallberg and Renman (2006), Hallberg et al. (2007).

The conditions for inclusion of a catchment area in the database were:

1. Samples are taken in a separate rain water conduction system. 
2. Catchment area size is under 200 ha. This value was selected to limit the complexity associated with the analysis of bigger catchment areas.

3. Pollution load determination is done by EMC. The adopted value of the EMC for each analyzed pollutant corresponds to the average of the data provided.

4. Information exists on the following catchment characteristics:

- Location.

- Average Daily Traffic (ADT).

- Type of land use.

After the selection, the database was made up of 46 catchment areas, with common information on:

- $\quad$ TSS in $89 \%$ of cases (41 catchment areas).

- O\&G in $30 \%$ of cases (14 catchment areas).

- $\mathrm{Zn}$ in $54 \%$ of cases (25 catchment areas).

- $\mathrm{Cu}$ in $54 \%$ of cases (25 catchment areas).

- COD in $56 \%$ of cases (26 catchment areas).

A preliminary analysis of the data confirmed the normality of the different pollutant EMCs by the Shapiro-Wilk test. The results of this test show that the values of COD and O\&G fit within a normal distribution, but the values of TSS, $\mathrm{Zn}$ and $\mathrm{Cu}$ do not $(\mathrm{p}$-value $<0.05)$. After a logarithmic transformation, a normal distribution of the EMC of TSS, $\mathrm{Zn}$ and $\mathrm{Cu}$ values was obtained, agreeing with the results provided by Mitchell (2005). 
Then, the values of "Catchment size" and "ADT" were divided into quartiles, assigning to each quartile a label condition that could be: Low, Medium, High or Very High.

In the case of the type of land use in the catchment area, the following simplified groups were considered, taking into account the description in each of the papers considered:

- Commercial.

- Residential (outskirts of a city).

- Rural.

- Roadway.

- Urban (center of the city).

With the values of the pollutants grouped by categories, a statistical analysis was carried out with the SPSS program.

\section{ANALYSIS}

In order to evaluate the influence of the different catchment characteristics on the variation of the selected water quality parameters, different ANOVA tests were done, all of them with a significance level of 0.05 . A summary of the ANOVAs can be seen in Table 1.

\section{Total Suspended Solids}

The ANOVA determined that EMC for different continents does not show significant statistical variations. Similarly, the influence of the other catchment 
area characteristics was compared. The result of these comparisons was that the catchment size, the type of land use and the ADT does not have statistical relevance in the variation of the pollutant EMC of the catchment area, in agreement with the conclusions of Crabtree et al. (2006). In Figure 1, the variation of the EMC of TSS is shown for the analyzed catchment characteristics.

\section{Oils and Grease}

In the case of the O\&G, valid data were only available from America and Asia. Most of the information on Europe corresponds to combined sewer systems and in the case of separate systems there is no information about O\&G.

In this case, the t-test showed that the EMC for America and Asia does not present significant statistical variations, similarly to the case of TSS. The influence of the catchment area characteristics was analyzed for the EMC of O\&G. For the catchment area size and type of land use, it was determined that these variables did not have statistical relevance in the variation of pollutant EMC. With respect to the ADT, it was determined that there is a significant statistical difference at a confidence level of $95 \%$. Thus the traffic really influences the O\&G EMC, while neither the catchment area size nor the land use does.

Applying Tukey's test for the different categories of ADT, it was concluded that the category High shows differences compared with the categories Low and Medium, but it is not possible to differentiate it from the Very High category. The 
comparison between the other categories (Low, Medium and Very High) did not present differences according to this analysis. The High traffic behaves differently as it has different characteristics which cause the statistical $p$-value for ANOVA be lower than 0.05. In Figure 2, the EMC of O\&G is shown for the analyzed catchment area characteristics.

\section{Zinc.}

The results of the ANOVA for $\mathrm{Zn}$ conclude that there is a significant statistical difference for the different continents. Applying Tukey's test, it was determined that the results from Asian investigations were different to the European and American ones. For the European and American data, significant statistical differences were not found. This is shown in the first graph in Figure 3.

The analysis of the influence of the other different catchment area characteristics shows that there are no statistical differences caused by the different catchment area sizes, land uses or ADT (Figure 3).

\section{Copper.}

As in the case of TSS by continent, the ANOVA shows that there are no significant statistical differences for EMC of $\mathrm{Cu}$, as is shown in Figure 4.

The analysis of the other different catchment area characteristics indicates that there is no significant statistical difference for the values of Log EMC of $\mathrm{Cu}$ associated with catchment area size or land use, but there is in the case of the ADT groups (Figure 4). 
Tukey's analysis of ADT values showed that the Low category has differences compared to the High category. Nevertheless, the Medium category does not show differences compared to the categories High and Low

\section{Chemical Oxygen Demand}

In the case of COD, only Gnecco et al. (2005) carried out research valid in Europe, so this continent was not included in the ANOVA, only America and Asia being considered for the comparison. The t-test results for the continents considered show that there are no differences between the EMC of COD, as is shown in Figure 5.

In a similar way to the other runoff pollutants studied, the analysis does not aid in the appreciation of significant differences in the EMC of COD for most of the catchment area characteristics. Only in the case of the land use do significant statistical differences appear among the categories (Figure 5). Tukey's test indicates that the EMCs of the urban zones are different from the rest of land use categories.

\section{DISCUSSION}

The lack of significant differences in the EMC of runoff pollutant for the studied characteristics can be explained by the fact that all the studies were carried out with similar catchment elements. The environment conditions were clearly different in a rural area to those in an urban one, but in both cases the study focuses on the same issue: what happens in impervious pavements under 
specific traffic conditions. Therefore, this could be considered a similar element in which the changes in the environment do not have a great significance in the measurements.

Another reason for this lack of influence of the catchment area characteristics studied may be the consideration of small basins (less than $2 \mathrm{~km} 2$ ) without industry. In this type of catchment areas, effects such as urban densification would not have much relevance, as would be expected in large urban catchment areas or in highly industrialized areas.

An interesting point is that the ADT is the only factor that shows significant statistical differences in the Cu and O\&G pollutants.

Regarding the case of $\mathrm{Cu}$, the extreme groups (Low and High) can be clearly differentiated. In contrast, these groups do not differ from the Medium category. The explanation is that when ADT increases, the consequence is that the concentration of $\mathrm{Cu}$ increases too, but the increase rate is small, so that the point where the differentiation occurs is within the Medium category. This leads to the formation of two groups, one containing the category Low and Medium and another group that includes the categories Medium and High.

In the case of O\&G, a particular effect is produced. The category High differs from Very High but not from Low or Medium, likewise, the category Very High does not differ from the categories Low and Medium, so that two groups are formed, Low-Medium-High and Low-Medium-Very High. This effect cannot be 
explained with the information compiled. Therefore more analysis must be done on the influence of the ADT on the O\&G with a greater number of basins.

\section{CONCLUSIONS.}

The main findings of the analysis carried out and presented in this paper are:

- The EMC of TSS, Zn and Cu have a Log distribution; while the EMC of COD and $O \& G$ have a normal distribution.

- The EMC of TSS calculated from studies focused on America, Asia and Europe does not have statistically significant differences, so it is possible to make comparisons between the concentrations measured in different places in these continents.

- The EMC of TSS in catchment areas of less than 200 ha. does not depend on the catchment area size, traffic (ADT) or type of land use.

- The EMC of O\&G does not show statistical difference between Asia and America. In this case, there was no information from Europe because the sewer systems analyzed are mainly combined and in the case of separate systems the papers did not contain information about the O\&G.

- The catchment area's size and the type of land use do not have statistically significant influence on the EMC of O\&G in Asia and America. 
- The EMC of $\mathrm{Zn}$ is higher in Asia than in America or Europe.

- Catchment area size and traffic (ADT) do not have influence on the EMC of $\mathrm{Zn}$ in America and Europe. In the case of the type of land use, the analysis is not conclusive.

- The EMC of $\mathrm{Cu}$ and COD are similar for the continents studied.

- The catchment size does not have influence on CU and COD concentration. However, the ADT presents differences for $\mathrm{Cu}$ and the land use shows differences for COD.

\section{ACKNOWLEDGEMENT}

This paper was possible thanks to the research project entitled "Development of New Systems of in-Situ Reception, Pre-Treatment and Treatment of Water Contaminated by Hydrocarbons from Urban Runoff in Car Parks with Impermeable Pavements (TRAPI)" (CTM2006 00310/TECNO) carried out by the Construction Technology Research Group (GITECO) of the University of Cantabria, with the support of the Spanish Ministry of Science and Technology, as a part of the "Projects of Scientific Research and Technological Development" program.

\section{REFERENCES.}


Barbosa, A. E., and Hvitved-Jacobsen, T. (1999). "Highway runoff and potential for removal of heavy metals in an infiltration pond in Portugal." Sci. Total Environ., 235(1-3), 151-159.

Barrett, M. E., Irish, L. B., Jr., Malina, J. F., Jr., and Charbeneau, R. J. (1998a). "Characterization of highway runoff in Austin, Texas, Area." Journal of Environmental Engineering, 124(2), 131-137.

Barrett, M. E., Walsh, P. M., Malina J. F., J., and Charbeneau, R. J. (1998b). "Performance of vegetative controls for treating highway runoff." $\mathrm{J}$. Environ. Eng., 124(11), 1121-1128.

Behera, P. K., Adams, B. J., and Li, J. Y. (2006). "Runoff quality analysis of urban catchments with analytical probabilistic models." J. Water Resour. Plann. Manage., 132(1), 4-14.

Boving, T. B., and Neary, K. (2006). "Attenuation of polycyclic aromatic hydrocarbons from urban stormwater runoff by wood filters." Journal of Contaminant Hydrology, doi:10.1016/j.jconhyd.2006.08.009.

Brown, J. N., and Peake, B. M. (2006). "Sources of heavy metals and polycyclic aromatic hydrocarbons in urban stormwater runoff." Science of the Total Environment, 359 145-155.

Charbeneau, R. J., and Barrett, M. E. (1998). "Evaluation of methods for estimating stormwater pollutant loads." Water Environmental Research, 70(7), 1295-1302.

Crabtree, B., Moy, F., Whitehead, M., and Reo, A. (2006). "Monitoring pollutants in highway runoff." Water and Environment Journal., 20 287-294. 
Dean, C. M., Sansalone, J. J., Cartledge, F. K., and Pardue, J. H. (2005). "Influence of hydrology on rainfall-runoff metal element speciation." J. Environ. Eng., 131(4), 632-642.

Flint, K. R., and Davis, A. P. (2007). "Pollutant mass flushing characterization of highway stormwater runoff from an ultra-urban area." J. Environ. Eng., 133(6), 616-626.

Fulkerson, M., Nnadi, F. N., and Chasar, L. S. (2007). "Characterizing dry deposition of mercury in urban runoff." Water Air Soil Pollut., 185(1-4), 21-32.

Gan, H., Zhuo, M., Li, D., and Zhou, Y. (2008). "Quality characterization and impact assessment of highway runoff in urban and rural area of Guangzhou, China." Environ. Monit. Assess., 140(1-3), 147-159.

Gnecco, I., Berretta, C., Lanza, L. G., and La Barbera, P. (2005). "Storm water pollution in the urban environment of Genoa, Italy." Atmos. Res., 77(1-4 SPEC. ISS.), 60-73.

Göbel, P., Dierkes, C., and Coldewey, W. G. (2006). "Storm water runoff concentration matrix for urban areas." Journal of Contaminant Hydrology, doi:10.1016/j.jconhyd.2006.08.008.

Hallberg, M., and Renman, G. (2006). "Assessment of suspended solids concentration in highway runoff and its treatment implication." Environ. Technol., 27(9), 945-950.

Hallberg, M., Renman, G., and Lundbom, T. (2007). "Seasonal variations of ten metals in highway runoff and their partition between dissolved and particulate matter." Water Air Soil Pollut., 181(1-4), 183-191. 
Han, Y. H., Lau, S. L., Kayhanian, M., and Stenstrom, M. K. (2006). "Correlation analysis among highway stormwater pollutants and characteristics." Water Sci. Technol., 53(2), 235-243.

Heyvaert, A. C., Reuter, J. E., and Goldman, C. R. (2006). "Subalpine, cold climate, stormwater treatment with a constructed surface flow wetland." J. Am. Water Resour. Assoc., 42(1), 45-54.

Irish, L. B., Jr., Barrett, M. E., Malina, J. F., Jr., and Charbeneau, R. J. (1998). "Use of regression models for analyzing highway storm-water loads." Journal of Environmental Engineering, 124(10), 987-993.

Kayahanian, M., Suverkropp, C., Ruby, A., and Tsay, K. (2007). "Characterization and prediction of highway runoff constituent event mean concentration." Journal of Environmental Management, doi:10.1016/j.jenvman.2006.09.024.

Khan, S., Lau, S., Kayahanian, M., and Stenstrom, M. K. (2006). "Oil and Grease Measurement in Highway Runoff-Sampling. Time and Event Mean Concentrations." JOURNAL OF ENVIRONMENTAL ENGINEERING, 132(3), 415-422.

Kim, L., Ko, S., Jeong, S., and Yoon, J. (2007). "Characteristics of washed-off pollutants and dynamic EMCs in parking lots and bridges during a storm." Sci. Total Environ., 376(1-3), 178-184.

Lau, S., Ma, J., Kayhanian, M., and Stenstrom, M. K. (2002). "First flush of organics in highway runoff." Proceedings of the Ninth International Conference on Urban Drainage (9ICUD), Portland, Oregon, United States, September 8-13, 1-12 
Lee, B. C., Matsui, S., Shimizu, Y., and Matsuda, T. (2005). "Characterizations of the first flush in storm water runoff from an urban roadway." Environ. Technol., 26(7), 773-782.

Lee, J. H., and Bang, K. W. (2000). "CHARACTERIZATION OF URBAN STORMWATER RUNOFF." Water Research, 34(6), 1773-1780.

Legret, M., and Colandini, V. (1999). "Effects of a porous pavement with reservoir structure on runoff water: water quality and fate of heavy metals." Water Science and Technology, 39(2), 111.

Li, M. -., Barrett, M. E., Rammohan, P., Olivera, F., and Landphair, H. C. (2008). "Documenting stormwater quality on Texas highways and adjacent vegetated roadsides." J. Environ. Eng., 134(1), 48-59.

Mitchell, G. (2005). "Mapping hazard from urban non-point pollution: A screening model to support sustainable urban drainage planning." J. Environ. Manage., 74(1), 1-9.

Pettersson, T. J. R., German, J., and Svensson, G. (1999). "Pollutant removal efficiency in two stormwater ponds in Sweden." PhD thesis, Chalmers Tekniska Hogskola, Goteborg, Sweden.

Prestes, E. C., Dos Anjos, V. E., Sodré, F. F., and Grassi, M. T. (2006). "Copper, lead and cadmium loads and behavior in urban stormwater runoff in Curitiba, Brazil." J. Braz. Chem. Soc., 17(1), 53-60.

Sansalone, J. J., Koran, J. M., Smithson, J. A., and Buchberger, S. G. (1998). "Physical characteristics of urban roadway solids transported during rain events." Journal of Environmental Engineering, 124(5), 427-440.

Soller, J., Stephenson, J., Olivieri, K., Downing, J., and Olivieri, A. W. (2005). "Evaluation of seasonal scale first flush pollutant loading and implications 
for urban runoff management." Journal of Environmental Management, 76 309-318.

Stotz, G., and Krauth, K. (1994). "The pollution of effluents from pervious pavements of an experimental highway section: first results." Vol. 146147 pp. $465-470$.

Thomson, N. R., Mcbean, E. A., Snodgrass, W., and Monstrenko, I. B. (1997). "Highway stormwater runoff quality: Development of surrogate parameter relationships." WATER AIR SOIL POLLUT., 94(3-4), 307-347.

Tuccillo, M. E. (2006). "Size fractionation of metals in runoff from residential and highway storm sewers." Science of the Total Environment, 355 288-300.

Wu, S., Allan, C. J., Saunders, W. L., and Evett, J. B. (1998). "Characterization and pollutant loading estimation for highway runoff." Journal of Environmental Engineering, 124(7), 584-592.

Zhang, W., Zhang, S., Yue, D., Wan, C., Ye, Y., and Wang, X. (2008). "Characterization and loading estimation of polycyclic aromatic hydrocarbons in road runoff from urban regions of Beijing, China." Environ. Toxicol. Chem., 27(1), 31-37. 
List of Figures:

Figure 1. Variation of the Log EMC of TSS for the analyzed catchment characteristics.

Figure 2. Variation of EMC of $O \& G$ for the analyzed catchment area characteristics.

Figure 3. Variation of Log EMC of $\mathrm{Zn}$ for the analyzed catchment area characteristics.

Figure 4. Variation of Log EMC of $\mathrm{Cu}$ for the analyzed catchment area characteristics.

Figure 5. Variation of EMC of COD for the analyzed catchment area characteristics. 
Journal of Irrigation and Drainage Engineering. Submitted April 17, 2012; accepted April 1, 2013; posted ahead of print April 3, 2013. doi:10.1061/(ASCE)IR.1943-4774.0000617
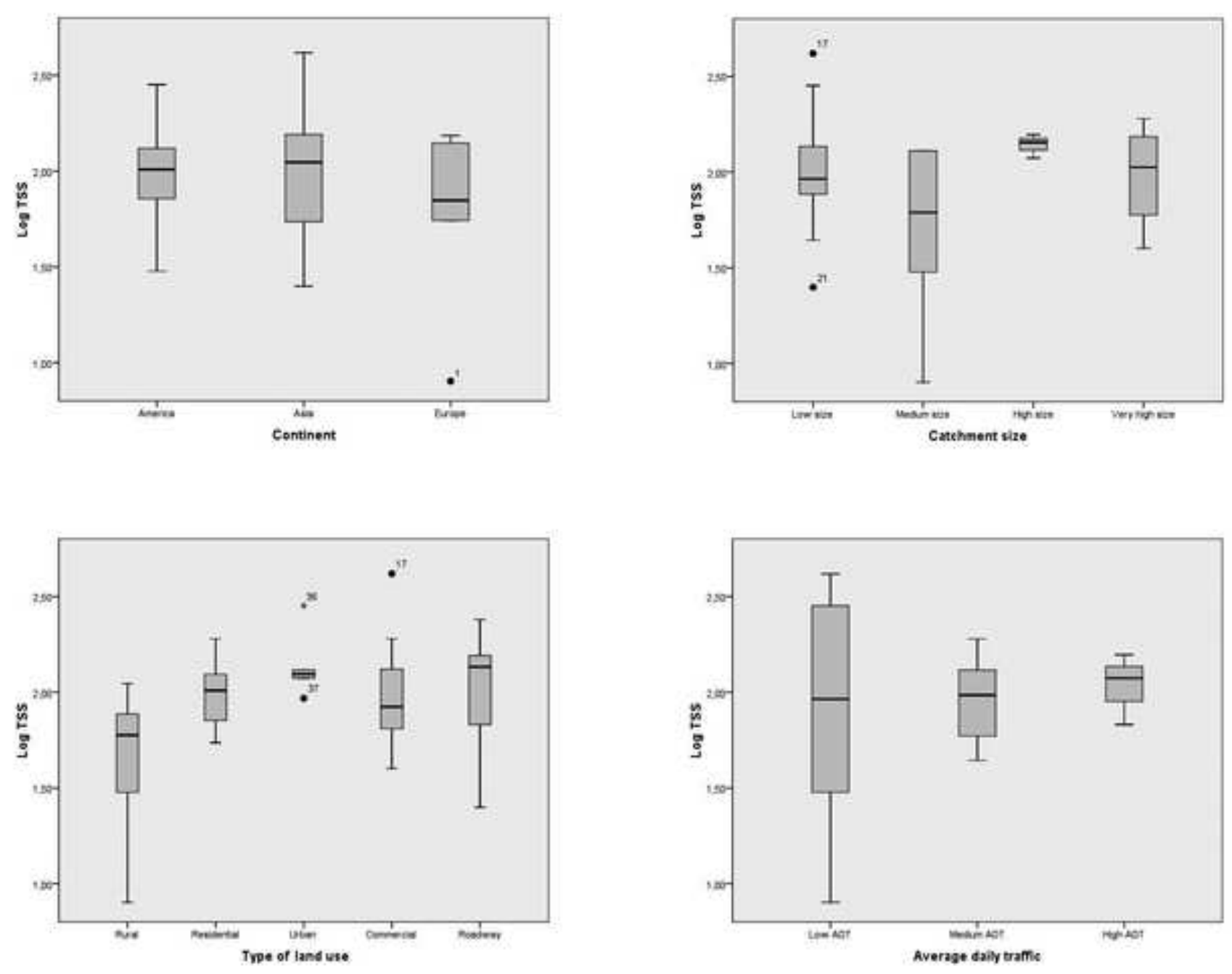

Copyright 2013 by the American Society of Civil Engineers

J. Irrig. Drain Eng. 
Journal of Irrigation and Drainage Engineering. Submitted April 17, 2012; accepted April 1, 2013; posted ahead of print April 3, 2013. doi:10.1061/(ASCE)IR.1943-4774.0000617
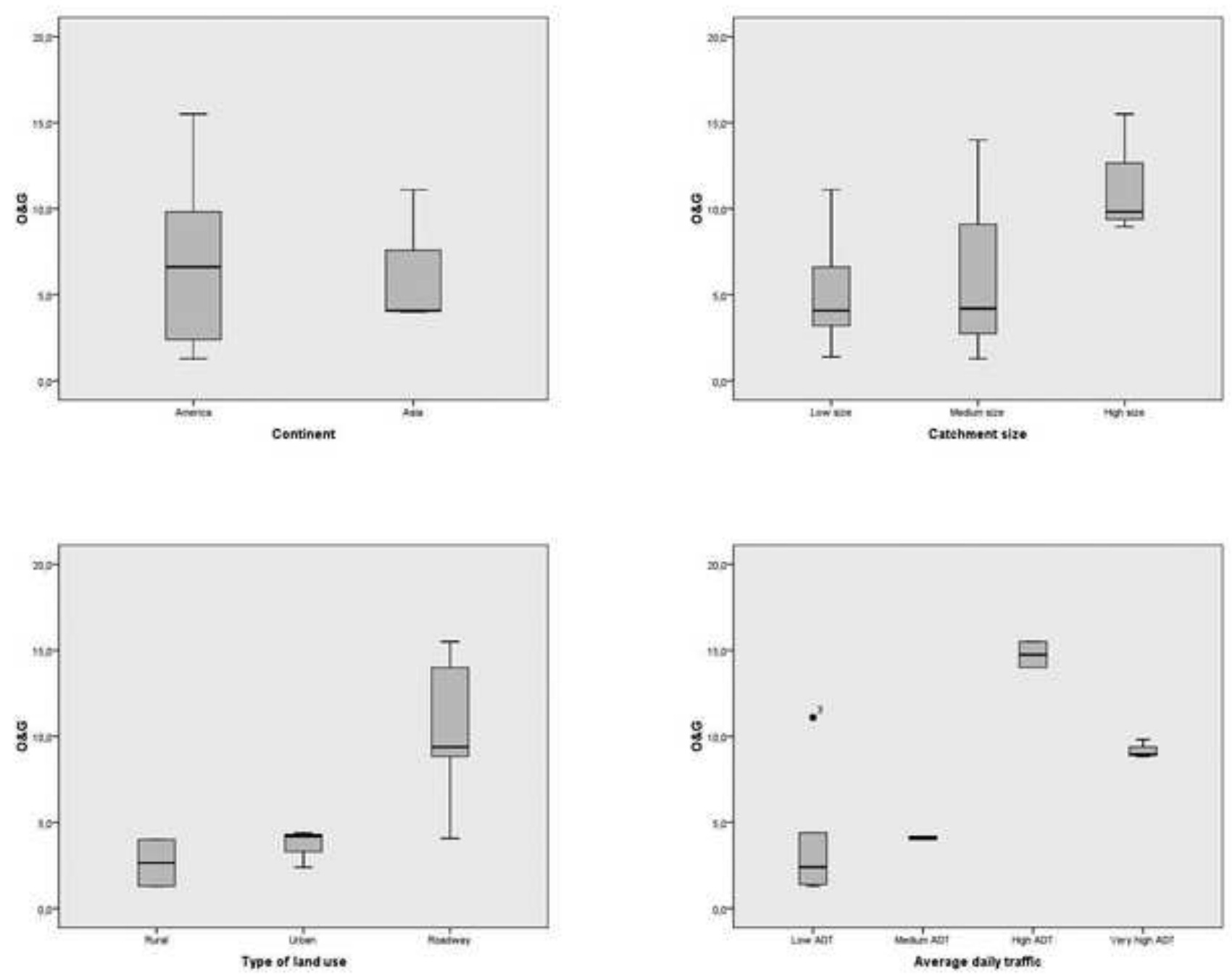

Copyright 2013 by the American Society of Civil Engineers 
Journal of Irrigation and Drainage Engineering. Submitted April 17, 2012; accepted April 1, 2013; posted ahead of print April 3, 2013. doi:10.1061/(ASCE)IR.1943-4774.0000617
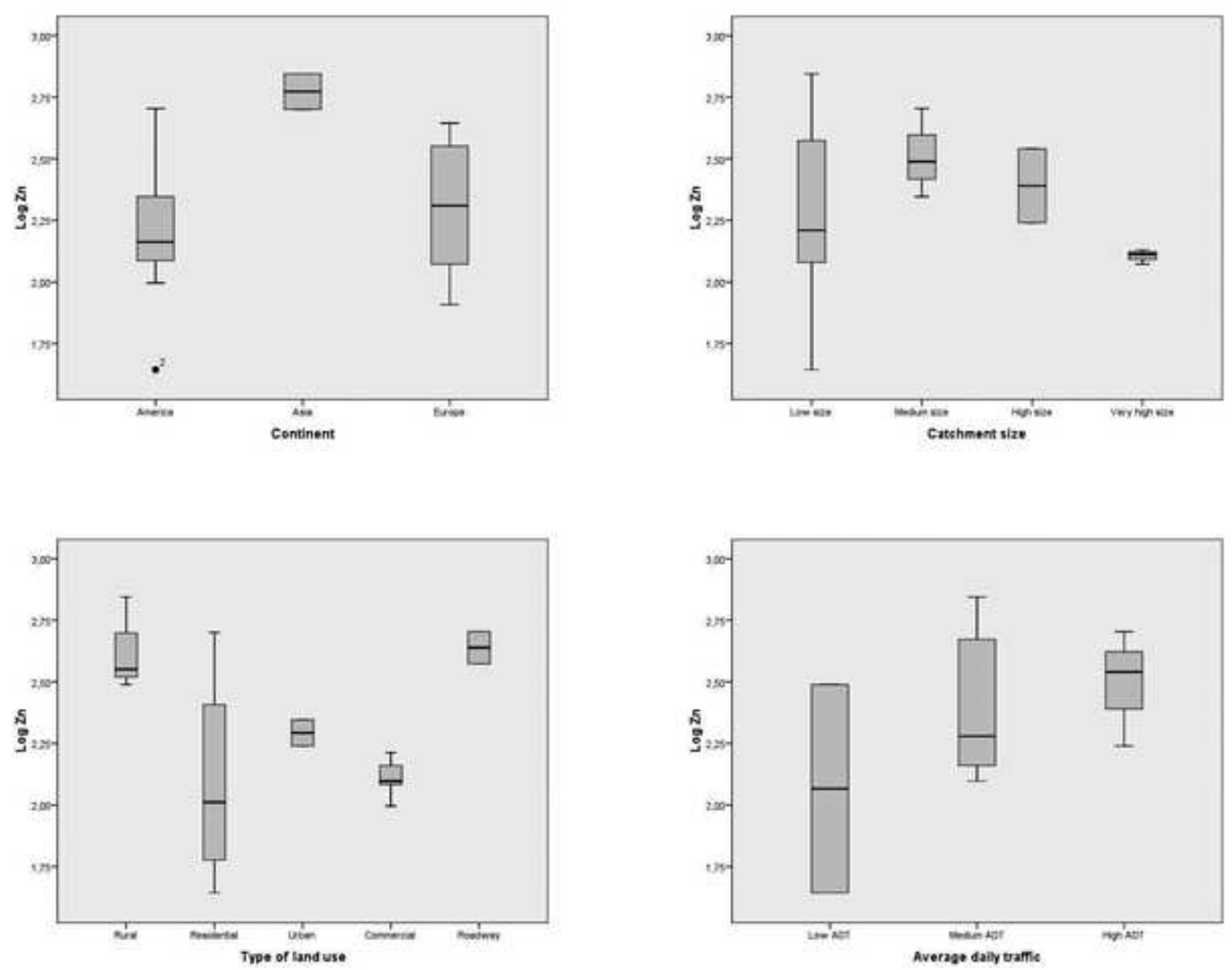

Copyright 2013 by the American Society of Civil Engineers 
Journal of Irrigation and Drainage Engineering. Submitted April 17, 2012; accepted April 1, 2013; posted ahead of print April 3, 2013. doi:10.1061/(ASCE)IR.1943-4774.0000617
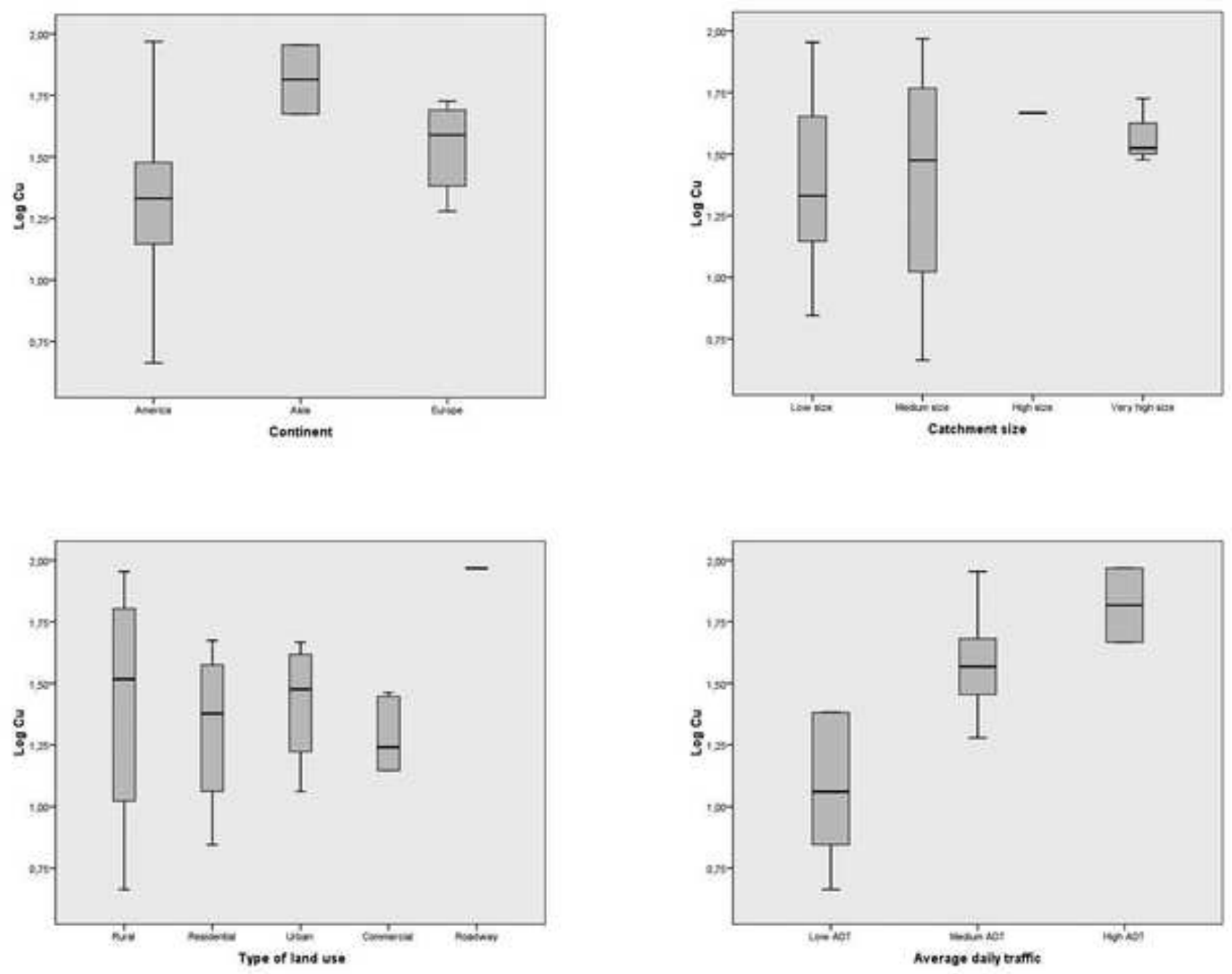

Copyright 2013 by the American Society of Civil Engineers 
Journal of Irrigation and Drainage Engineering. Submitted April 17, 2012; accepted April 1, 2013; posted ahead of print April 3, 2013. doi:10.1061/(ASCE)IR.1943-4774.0000617
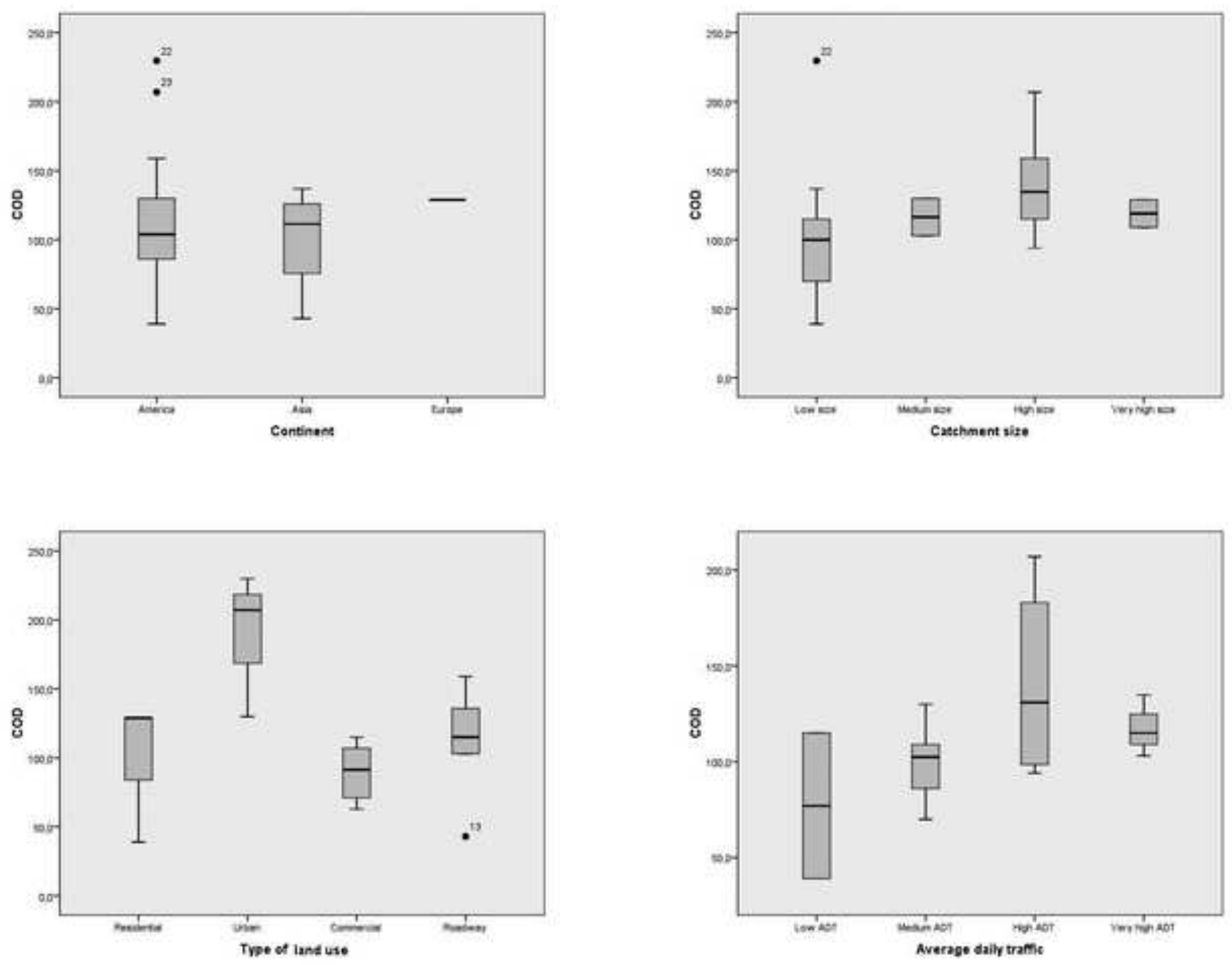

Copyright 2013 by the American Society of Civil Engineers

J. Irrig. Drain Eng. 
Table 1. Summary of ANOVAs

\begin{tabular}{|c|c|c|c|c|c|c|c|}
\hline \multicolumn{8}{|c|}{ ANOVA } \\
\hline & & & Sum of Squares & $\mathrm{df}$ & Mean Square & $\mathrm{F}$ & Sig. \\
\hline \multirow{4}{*}{ Log TSS } & Continent & $\begin{array}{l}\text { Between Groups } \\
\text { Within Groups } \\
\text { Total } \\
\end{array}$ & $\begin{array}{r}.241 \\
3.335 \\
3.576 \\
\end{array}$ & $\begin{array}{r}2 \\
35 \\
37 \\
\end{array}$ & $\begin{array}{l}.121 \\
.095\end{array}$ & 1.266 & .294 \\
\hline & Catchment Area Size & $\begin{array}{l}\text { Between Groups } \\
\text { Within Groups } \\
\text { Total } \\
\end{array}$ & $\begin{array}{r}.564 \\
3.012 \\
3.576 \\
\end{array}$ & $\begin{array}{r}3 \\
34 \\
37 \\
\end{array}$ & $\begin{array}{l}.188 \\
.089\end{array}$ & 2.123 & .115 \\
\hline & Land Uses & $\begin{array}{l}\text { Between Groups } \\
\text { Within Groups } \\
\text { Total }\end{array}$ & $\begin{array}{r}.790 \\
2.609 \\
3.399 \\
\end{array}$ & $\begin{array}{r}4 \\
29 \\
33 \\
\end{array}$ & $\begin{array}{l}.197 \\
.090\end{array}$ & 2.196 & .094 \\
\hline & Average Daily Traffic & $\begin{array}{l}\text { Between Groups } \\
\text { Within Groups } \\
\text { Total } \\
\end{array}$ & $\begin{array}{r}.038 \\
2.404 \\
2.442 \\
\end{array}$ & $\begin{array}{r}2 \\
14 \\
16 \\
\end{array}$ & $\begin{array}{l}.019 \\
.172\end{array}$ & .112 & .895 \\
\hline \multirow{4}{*}{$\log Z n$} & Continent & $\begin{array}{l}\text { Between Groups } \\
\text { Within Groups } \\
\text { Total } \\
\end{array}$ & $\begin{array}{r}.554 \\
1.398 \\
1.952 \\
\end{array}$ & $\begin{array}{r}2 \\
19 \\
21 \\
\end{array}$ & $\begin{array}{l}.277 \\
.074\end{array}$ & 3.765 & .042 \\
\hline & Catchment Area Size & $\begin{array}{l}\text { Between Groups } \\
\text { Within Groups } \\
\text { Total } \\
\end{array}$ & $\begin{array}{r}.307 \\
1.645 \\
1.952 \\
\end{array}$ & $\begin{array}{r}3 \\
18 \\
21 \\
\end{array}$ & $\begin{array}{l}.102 \\
.091\end{array}$ & 1.121 & .367 \\
\hline & Land Uses & $\begin{array}{l}\text { Between Groups } \\
\text { Within Groups } \\
\text { Total } \\
\end{array}$ & $\begin{array}{r}.958 \\
.728 \\
1.686 \\
\end{array}$ & $\begin{array}{r}4 \\
13 \\
17 \\
\end{array}$ & $\begin{array}{l}.240 \\
.056\end{array}$ & 4.282 & .020 \\
\hline & Average Daily Traffic & $\begin{array}{l}\text { Between Groups } \\
\text { Within Groups } \\
\text { Total } \\
\end{array}$ & $\begin{array}{r}.237 \\
1.066 \\
1.303 \\
\end{array}$ & $\begin{array}{r}2 \\
10 \\
12 \\
\end{array}$ & $\begin{array}{l}.118 \\
.107\end{array}$ & 1.111 & .367 \\
\hline \multirow{4}{*}{$\log \mathrm{Cu}$} & Continent & $\begin{array}{l}\text { Between Groups } \\
\text { Within Groups } \\
\text { Total }\end{array}$ & $\begin{array}{r}.575 \\
1.669 \\
2.244 \\
\end{array}$ & $\begin{array}{r}2 \\
19 \\
21\end{array}$ & $\begin{array}{l}.288 \\
.088\end{array}$ & 3.274 & .060 \\
\hline & Catchment Area Size & $\begin{array}{l}\text { Between Groups } \\
\text { Within Groups } \\
\text { Total } \\
\end{array}$ & $\begin{array}{r}.168 \\
2.076 \\
2.244 \\
\end{array}$ & $\begin{array}{r}3 \\
18 \\
21 \\
\end{array}$ & $\begin{array}{l}.056 \\
.115\end{array}$ & .484 & .697 \\
\hline & Land Uses & $\begin{array}{l}\text { Between Groups } \\
\text { Within Groups } \\
\text { Total } \\
\end{array}$ & $\begin{array}{r}.431 \\
1.608 \\
2.039 \\
\end{array}$ & $\begin{array}{r}4 \\
14 \\
18 \\
\end{array}$ & $\begin{array}{l}.108 \\
.115\end{array}$ & .937 & .471 \\
\hline & Average Daily Traffic & $\begin{array}{l}\text { Between Groups } \\
\text { Within Groups } \\
\text { Total }\end{array}$ & $\begin{array}{r}1.122 \\
.741 \\
1.863\end{array}$ & $\begin{array}{r}2 \\
11 \\
13\end{array}$ & $\begin{array}{l}.561 \\
.067\end{array}$ & 8.329 & .006 \\
\hline
\end{tabular}


Journal of Irrigation and Drainage Engineering. Submitted April 17, 2012; accepted April 1, 2013; posted ahead of print April 3, 2013. doi:10.1061/(ASCE)IR.1943-4774.0000617

\begin{tabular}{|c|c|c|c|c|c|c|c|}
\hline \multirow{4}{*}{ COD } & Continent & $\begin{array}{l}\text { Between Groups } \\
\text { Within Groups } \\
\text { Total }\end{array}$ & $\begin{array}{r}843.185 \\
43601.530 \\
44444.715\end{array}$ & $\begin{array}{r}2 \\
20 \\
22\end{array}$ & $\begin{array}{r}421.592 \\
2180.077\end{array}$ & .193 & .826 \\
\hline & Catchment Area Size & $\begin{array}{l}\text { Between Groups } \\
\text { Within Groups } \\
\text { Total } \\
\end{array}$ & $\begin{array}{r}6716.411 \\
37728.304 \\
44444.715 \\
\end{array}$ & $\begin{array}{r}3 \\
19 \\
22 \\
\end{array}$ & $\begin{array}{l}2238.804 \\
1985.700\end{array}$ & 1.127 & .363 \\
\hline & Land Uses & $\begin{array}{l}\text { Between Groups } \\
\text { Within Groups } \\
\text { Total } \\
\end{array}$ & $\begin{array}{l}22268.203 \\
21835.489 \\
44103.693 \\
\end{array}$ & $\begin{array}{r}4 \\
17 \\
21 \\
\end{array}$ & $\begin{array}{l}5567.051 \\
1284.441\end{array}$ & 4.334 & .013 \\
\hline & Average Daily Traffic & $\begin{array}{l}\text { Between Groups } \\
\text { Within Groups } \\
\text { Total }\end{array}$ & $\begin{array}{l}22243.236 \\
21835.489 \\
44078.726 \\
\end{array}$ & $\begin{array}{r}3 \\
17 \\
20 \\
\end{array}$ & $\begin{array}{l}7414.412 \\
1284.441\end{array}$ & 5.772 & .007 \\
\hline \multirow{4}{*}{$O \& G$} & Continent & $\begin{array}{l}\text { Between Groups } \\
\text { Within Groups } \\
\text { Total } \\
\end{array}$ & $\begin{array}{r}82.737 \\
187.483 \\
270.220 \\
\end{array}$ & $\begin{array}{r}2 \\
10 \\
12 \\
\end{array}$ & $\begin{array}{l}41.368 \\
18.748\end{array}$ & 2.207 & .161 \\
\hline & Catchment Area Size & $\begin{array}{l}\text { Between Groups } \\
\text { Within Groups } \\
\text { Total } \\
\end{array}$ & $\begin{array}{r}180.580 \\
89.640 \\
270.220 \\
\end{array}$ & $\begin{array}{r}4 \\
8 \\
12 \\
\end{array}$ & $\begin{array}{l}45.145 \\
11.205\end{array}$ & 4.029 & .044 \\
\hline & Land Uses & $\begin{array}{l}\text { Between Groups } \\
\text { Within Groups } \\
\text { Total } \\
\end{array}$ & $\begin{array}{r}132.469 \\
89.640 \\
222.109 \\
\end{array}$ & $\begin{array}{r}2 \\
8 \\
10 \\
\end{array}$ & $\begin{array}{l}66.235 \\
11.205\end{array}$ & 5.911 & .027 \\
\hline & Average Daily Traffic & $\begin{array}{l}\text { Between Groups } \\
\text { Within Groups } \\
\text { Total }\end{array}$ & $\begin{array}{r}192.636 \\
68.837 \\
261.473\end{array}$ & $\begin{array}{r}3 \\
8 \\
11\end{array}$ & $\begin{array}{r}64.212 \\
8.605\end{array}$ & 7.463 & .010 \\
\hline
\end{tabular}

